Esta publicación cientifica en formato digital es continuidad de la revista impresa ISSN-Versión Impresa 0798-1406 / ISSN-Versión on line 2542-3185Depósito legal pp
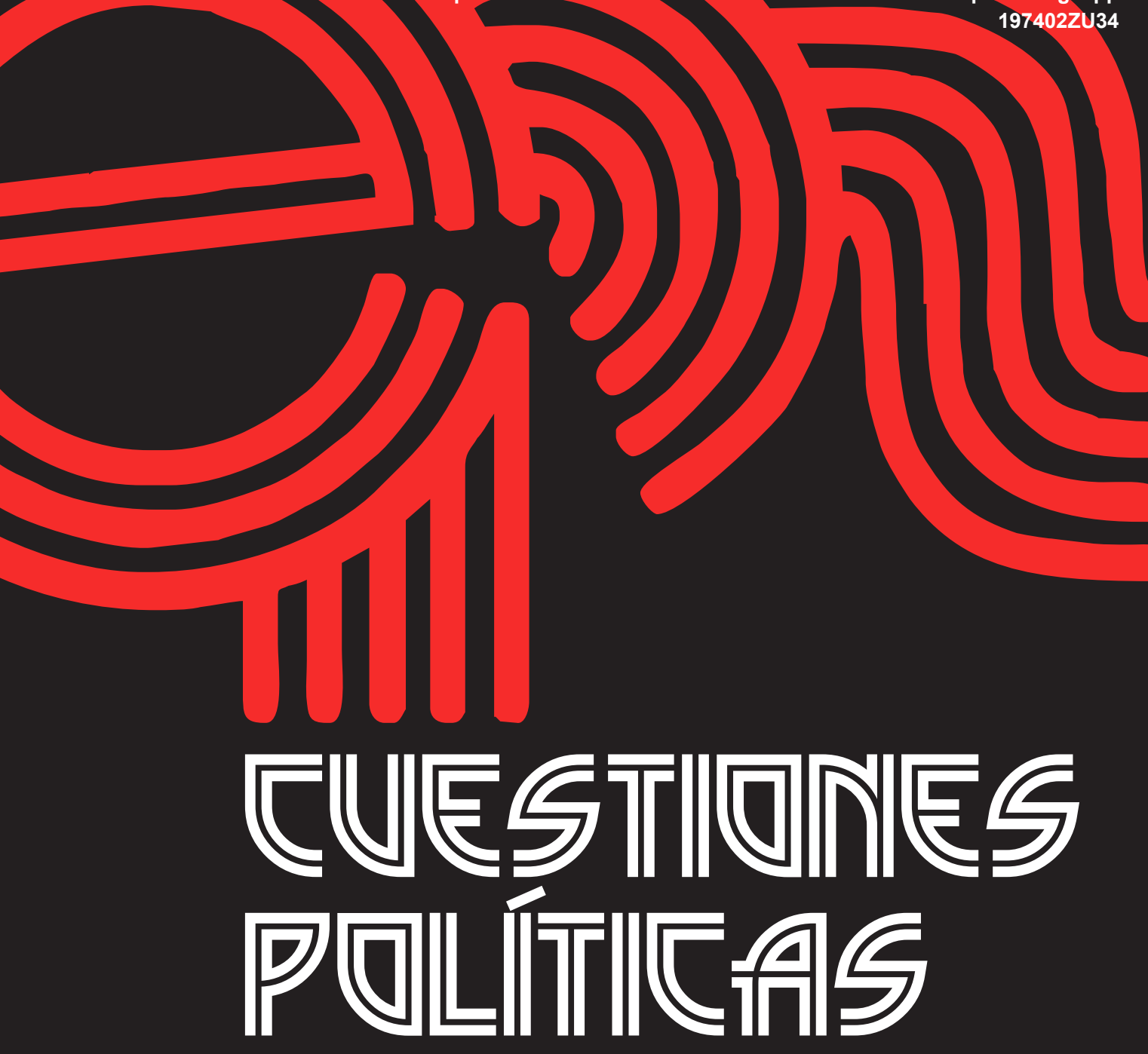

Instituto de Estudios Políticos y Derecho Público "Dr. Humberto J. La Roche" de la Facultad de Ciencias Jurídicas y Políticas de la Universidad del Zulia Maracaibo, Venezuela
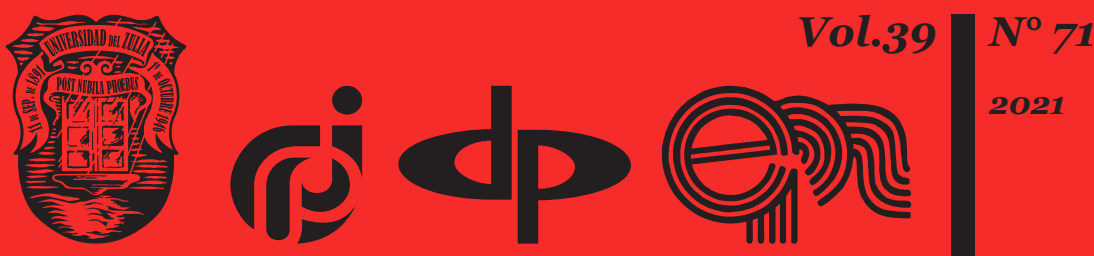


\title{
Anti-corruption mechanism in Ukraine: content actualization under the conditions of normative innovations
}

\author{
DOI: https://doi.org/10.46398/cuestpol.3971.59
}

Serhii V. Kivalov *

\begin{abstract}
The aim of the investigation was to determine the most appropriate avenues for further implementation of the European concept of anti-corruption. To carry out this article, general and special research methods have been applied, such as systems analysis, dialectical, formal logical and structural functional methods, as well as a series of empirical methods. Statistical analysis has been used to demonstrate anti-corruption measures, undertaken in 2016 - 2020. The anti-corruption mechanism has been analyzed through the prism of combined institutional and instrumental systems, with the aim of preventing corruption. The priorities for transforming the anti-corruption mechanism have been defined as follows: (a) increased accountability for corruption offences; (b) introduction and appropriate application of corruption detection tools. It is concluded that the current trend demonstrates a decline in the implementation of anti-corruption preventive tools in Ukraine due to the following factors: change of the vector of public interest towards compliance with antiCovid-19 measures, destabilization of authority and lack of collaboration between authorized subjects in solving corruption problems.
\end{abstract}

Keywords: anti-corruption mechanism; measures to combat corruption; institutional system; public sector; lifestyle of the reporting subjects. 


\section{Mecanismo anticorrupción en Ucrania: actualización de contenidos bajo las condiciones de innovaciones normativas}

\section{Resumen}

El objetivo de la investigación fue determinar las vías más adecuadas para una mayor implementación del concepto europeo de lucha contra la corrupción. Para llevar a cabo el presente artículo se han aplicado métodos de investigación generales y especiales, como el análisis de sistemas, los métodos dialécticos, lógicos formales y funcionales estructurales, así como una serie de métodos empíricos. El análisis estadístico se ha utilizado para demostrar las medidas anticorrupción, emprendidas en 2016 - 2020. El mecanismo anticorrupción se ha analizado a través del prisma de sistemas institucionales e instrumentales combinados, con el objetivo de prevenir la corrupción. Las prioridades para transformar el mecanismo anticorrupción se han definido de la siguiente manera: a) aumento de la responsabilidad por delitos de corrupción; b) introducción y aplicación adecuada de herramientas de detección de corrupción. Se concluye que la tendencia actual demuestra un declive en la implementación de herramientas preventivas anticorrupción en Ucrania debido a los siguientes factores: cambio del vector de interés público hacia el cumplimiento de las medidas anti-Covid-19, desestabilización de la autoridad y la falta de colaboración entre sujetos autorizados en resolver problemas de corrupción.

Palabras clave: mecanismo anticorrupción; medidas para combatir la corrupción; sistema institucional; sector público; estilo de vida de los sujetos declarantes.

\section{Introduction}

The need to discover effective tools to counteract corruption is primarily determined by the following factors: 1 ) reducing the negative impact from corruption on the country's economy; 2) boosting the population's trust in public sector; 3) improving Ukraine's image as a democratic, rule-oflaw and social state, seeking EU membership. The latter factor is further substantiated by the necessity to fulfill the commitments provided for by the Association Agreement between Ukraine and the European Union (2014).

The anticipated effect in counteracting corruption has failed to occur despite the legislative changes of basic character introduced in 2014 [(Law No. 1700-VII. 2014), legalization of lustration to protect and reinforce democratic values (Law No. 1682-VIII, 2014), as well as institutional [the establishment of: the National Agency for the Prevention of Corruption 
as the central body of executive power with a special status (Resolution No. 118, 2015), the National Anti-Corruption Bureau of Ukraine (Law No. 1698-VII, 2014), Specialized Anti-Corruption Prosecutor's Office of the Office of the Prosecutor General (Order No. 125, 2020), the Supreme Anti-Corruption Court (Law No. 2447-VIII. 2018.)]. However, it should be noted that the available positive trends in the formation of effective anticorruption mechanism is essential for the further intensification of work in this direction.

The need for specifying the national model of anti-corruption mechanism in correlation with the generally recognized European standards is conditioned by the absence of anti-corruption strategy, accounting for challenges of Covid-19 pandemic (Kivalov, 2020), rapid development of IT technologies and application thereof for administration and management (Hnatovska, Manzhosova, Marushchak, \& Oleksiy, 2019), and the national archetype of the civil society in Ukraine (Bila-Tiunova, Bilous-Osin, Kozachuk, \& Vasylkivska, 2019).

The lack of approved anti-corruption strategy serves as the destabilizing factor for the formulation of effective anti-corruption mechanism. The latest document of this nature was formally and legally approved in 2014 (Law No. 1699, 2014); the similar document for 2018-2020 has been drafted but not adopted instead (Draft Law No. 2017, 2017).

Presently, a new draft of state anti-corruption policy for 2020-2024 is available although it has not been approved either (Draft Law No. 2020, 2020). Accounting for the above-mentioned, the lack of unity in the relations of public authorities should be mentioned: President of Ukraine is in favor of stricter liability for corruption (Office of the President of Ukraine, 2021) whereas the National Agency for the Prevention of Corruption insists on the intensification of the available anti-corruption means. Thus, corruption prevention remains an acute problem for Ukraine and the current challenges dictate the rules to secure constant improvement of the chosen anti-corruption preventive approaches.

\section{Theoretical Framework or Literature Review}

The sphere of anti-corruption activities is characterized by its special significance for the state and the operation of its bodies as well as for the society at large.

The aim, pursued in this sphere determines the scope of the relations of the entities engaged in anti-corruption activities, the need in the most flexible instruments tested by the international community (Organization of American States, 1996; General Assembly, 1996; United Nations, 1997; 
United Nations, 2003). The combating corruption issue and the formulation of an efficient anti-corruption mechanism is an on-going issue; however, the constant evolution of social relations requires taking into consideration the new challenges posed by digitalization and humanization.

The main idea of corruption prevention dialectically lies in the following domain: 1) prevention of an offense; 2) prevention of arbitrariness on the part of officials, authorized to perform the functions of state power and local self-government. The former presumes the following criminological postulates: corruption offenses are rational (a non-deliberate corruption offense is impossible); prevention of corruption becomes possible due to the elimination of potential profit from corruption; reducing the effect from profit may occur due to the risk of the offense being revealed and the forthcoming bringing to liability (Khamkhodera, 2020b).

Thus, the corruption preventive mechanism may eventually be transformed through the following: a) enhanced liability for corruption: b) introduction and proper implementation of anti-corruption tools. The present research is focused on the latter.

Investigation of the issue of anti-corruption mechanism requires clarity in the approaches to its component parts, which is common to the activities in public sphere and non-managerial sphere Mykhailenko, 2017; 112). They include: 1) state anti-corruption policy, aimed at the creation of efficient detection of preconditions for the prevention, counteraction and removal of consequences of corruption offenses (Hudkov, 2018), which will facilitate the emergence of positive archetypes of the society; non-tolerance of corruption; 2) anti-corruption declaring as a complex of organizational and formal legal actions to secure the obligation of financial reporting, detection of violations of financial discipline and the implementation of administrative liability to physical persons, responsible for the violation of financial control requirements (Khabarova, 2017); 3) conflict of interests as the means of corruption prevention; 4) institutional system of combating corruption, based on the operation of specialized bodies of public authority, focused on anti-corruption measures; 5) lifestyle monitoring, aimed at revealing the correspondence between the living standards and the incomes, stated in the declaration.

Certain conclusions of academic nature might be of interest. They concern criteria of acceptability, contextual and applied motivation, exemption from liability for minor violations related to the conflict of interest (Khamkhodera, 2020a); specificity of anti-corruption declaring in Ukraine, manifested in: aiming at the prevention and detection of corruption and violation of anti-corruption requirements, prohibitions and restrictions; it is aimed at the verification of the financial status of the entities liable to anti-corruption laws; failure to observe anti-corruption declaring stipulates enforcement of liability measures, etc., (Kornuta et al., 2020). 


\section{Serhï V. Kivalov \\ 976 \\ Anti-corruption mechanism in Ukraine:content actualization under the conditions of normative innovations}

The present article researches into the anti-corruption mechanism as a combination of institutional and instrumental systems, aimed at counteracting corruption in public and private sectors. For consistent highlighting of the problem the author indicates the key aspects, which characterize the homogeneous group of social relations, dealing with combating corruption, establishing the model of anti-corruption mechanism; defining content features of lifestyle monitoring and the procedure of its implementation; defining the institutional system of corruption counteracting.

\section{Methodology}

General and special methods of academic cognition have been applied in this research, namely system analysis, dialectical method, formal logical and structural functional methods, as well as a number of empirical methods.

The method of systematic analysis was used by the author of the article to carefully study the current anti-corruption legislation of Ukraine in terms of its effectiveness. It is this method that led to the conclusion about the gaps in the current legislation of Ukraine, due to which the reduction of corruption is not fast enough. In particular, there is a lack of a clear procedure for monitoring the lifestyle of the subjects of the declaration.

The dialectical method, as a way of knowing objective activity in its development, allowed the author to study such a phenomenon as corruption in its development in accordance with the stages of state and society, and to propose tools to combat corruption, based on the modern period of social development. In particular, it is said that the normative consolidation of responsibility for corrupt acts alone is no longer enough, and the mechanism for detecting and counteracting corrupt acts in accordance with the best world standards needs to be improved.

Formal-logical method, as one that provides logical consistency and consistency of legal norms, helps to track the presence of the necessary internal elements in the formulation of concepts, as well as deriving logical consequences, helped the author to formulate general conclusions of the study, according to which the priority directions of transformation of the mechanism for prevention of corruption are: a) enhancement of responsibility for commission of corruption offenses; b) implementation and proper application of tools aimed at detecting corruption.

The structural-functional method, which consists in the systematic study of social phenomena and processes as a structurally dismembered integrity, where each element of the structure has a specific functional purpose, helped the author to conclude that there is no positive effect of a 
modern institute of monitoring the lifestyle of civil servants.

\section{Results and Discussion}

The research contains statistical analysis of specific anti-corruption measures, applied by the authorized anti-corruption bodies in 2016-2020. (Decision No. 32, 2017; Decision No. 2017, 2017; Decision No. 2018, 2018; Decision No. 2019, 2019; Decision No. 2020, 2020) of the following activities: comprehensive revisions, lifestyle monitoring, detection of violations in declarations, processing of reported cases on resolving conflicts of interest and related restrictions and bringing to administrative liability for violations in declarations (Table 1).

\begin{tabular}{|c|c|c|c|c|c|}
\hline Year & 2016 & 2017 & 2018 & 2019 & 2020 \\
\hline Anti-corruption measure & & & & & \\
\hline Comprehensive revisions & 11 & 30 & 35 & 54 & 80 \\
\hline Lifestyle monitoring & - & - & - & - & 47 \\
\hline Detection of violations in declarations & 1700 & 18700 & 17000 & 23000 & 16000 \\
\hline $\begin{array}{l}\text { Reported cases on resolving conflicts } \\
\text { of interest and related restrictions }\end{array}$ & 456 & 1577 & 1280 & 1500 & 2842 \\
\hline $\begin{array}{l}\text { Bringing to administrative liability for } \\
\text { declaration violations }\end{array}$ & 11 & 49 & 310 & 371 & 128 \\
\hline
\end{tabular}

Table 1. Quantity indices of the application of certain anticorruption measures in 2016-2020, data provided by Report on the activities of the National Agency for the Prevention of Corruption, 2020.

Thus, the following tendencies have been revealed: the number of comprehensive revisions reached its maximum in 2020 and is growing every year; lifestyle monitoring was initiated in 2020 and immediately reached its average quantity level; the number of detected declaration violations is characterized by constant fluctuations, reaching its maximum in 2019, however 2020 revealed comparatively small number of such violations; reported cases of resolving conflicts of interest and related restrictions show stable growth, proving the tendency of qualitative change in applying this anti-corruption measure; cases of bringing to administrative liability for 


\section{Serhï V. Kivalov \\ 978 \\ Anti-corruption mechanism in Ukraine:content actualization under the conditions of normative innovations}

declaration violations reached their maximum in 2019 and reduced three times in 2020, which correlates with the number of detected declaration violations.

Reduction in the positive tendencies of implementing preventive anticorruption measures could be explained by such factors as: intensified measures against Covid-19 pandemic, which resulted in the destabilization of public authorities efficient operation; the Constitutional Court of Ukraine ruling stating that certain provisions of the Law of Ukraine "On the Prevention of Corruption" (Law No. 1700-VII, 2014) and the Criminal Code of Ukraine (Law No. 2341-III, 2001), particularly the anti-corruption declaration provisions contradict the Constitution, and provisions on amending the Law of Ukraine "On the Prevention of Corruption" concerning the specific status of judges and Constitutional Court Justices as subjects, liable to preventive anti-corruption measures (Law No. 1079-IX, 2020).

Anti-corruption declaring is an established anti-corruption mechanism; however, due to certain objective reasons it has been losing its initial significance. The pattern of revealing signs of corruption was formally changed by the Law of Ukraine "On the Amendments to the Law of Ukraine 'On the Prevention of Corruption' Concerning the Restoration of the Institutional Mechanism for the Prevention of Corruption» (Law No. 1079-IX, 2020). These amendments resulted in recognizing as anticonstitutional certain provisions of anti-corruption laws as well as the Law of Ukraine "On Amendments to Certain Legislative Acts of Ukraine Concerning Ensuring the Effectiveness of the Institutional Mechanism for Preventing Corruption» (Law No. 140-IX, 2019). The elements of the anticorruption mechanism, which have been amended, are the following:

1) the legal status of the National Agency for the Prevention of Corruption has been changed in the part of its identity as a body, headed by Chairman, appointed by the Cabinet of Ministers, rather than a collegial body of five members as it used to be.

2) there was established a new provision involving a new subject authorized to exercise financial anti-corruption control (timely submission, correct and full declaring) who is an authorized unit (authorized official) of a state body or a military unit, exercising control over the subordinate staff, referred to Intelligence Service of Ukraine and/or whose activities involve state secrets (resulting from investigative, intelligence and counter-intelligence activity) and also over officials, seeking such positions, or those who have resigned.

3) the new provisions regarding applying anti-corruption instruments (comprehensive revision, lifestyle monitoring) to judges and Constitutional Court Justices have been made. The measures should be applied according to the following procedure: a) obtaining 
approval from the Supreme Council of Justice or Constitutional Court Justices assembly; b) immediate notification of the Supreme Council of Justice and the Chairman of the Constitutional Court about the start of a comprehensive revision or lifestyle monitoring; c) submitting the results of the applied anti-corruption measures in the report, approved by the Chairman of the National Agency for the Prevention of Corruption or his/her Deputy; d) granting judges or Constitutional Court Justices an opportunity to inform about the attempts to exercise unlawful influence, pressure, or interference into judicial activity undertaken by the staff of the National Agency for the Prevention of Corruption, Supreme Council of Justice or Constitutional Court Justices assembly.

4) introduction of the order of priority for submitting declarations to ensure comprehensive revision and notifying the subject of declaring about putting him/her on the list, etc.

Altogether, the designated changes do not characterize the current model of the anti-corruption mechanism, which is aimed at detecting corruption. On the contrary, they create a temporal opportunity of continuance of the abeyance of corruption offences.

Regarding the application of such a tool to prevent corruption as monitoring the lifestyle of the declarants, the positive effect of this novelty of anti-corruption legislation has not been corroborated in practice due to the following factors: 1 ) since the introduction of this measure of anticorruption financial control, the procedure for monitoring lifestyle has not been adopted; 2) the lack of differentiation of certain aspects of the application of lifestyle monitoring to specific subjects of declaration, which is associated with the specifics of their functions; 3) accompanying phenomena that indirectly affected the lack of priority in solving the issues of lifestyle monitoring (e.g., lack of constructive cooperation between anticorruption state bodies and judicial bodies, increased social and political tensions in connection with the spread of Covid-19 pandemic, etc.).

Emphasis should be placed on the lack of the procedure of monitoring the lifestyle of the declarants. Initially, an attempt to introduce a normatively established procedure for monitoring lifestyle was recorded in 2017 in the form of a draft decision of the National Agency for the Prevention of Corruption (Draft Decision No. 13, 2017). In response to the request to the National Agency for the Prevention of Corruption regarding the existence of adopted regulations relating to the application of lifestyle monitoring of March 12, 2021, the response was provided, the text of which testifies to the following: a) monitoring the lifestyle of declaring entities is carried out in accordance with the provisions of the Law of Ukraine «On the Prevention of Corruption» in Art. 12, 13, 514 (LAW No. 1700-VII, 2014); b) by-laws on the mechanism of application of lifestyle monitoring have not been adopted (Response No, 2021, 2021)1. 
This position of the National Agency for the Prevention of Corruption regarding the lack of the need to adopt a separate procedure for monitoring lifestyle can be justified by the wording of Part 3 of Art. 514 of the Law of Ukraine «On the Prevention of Corruption»: «The procedure for monitoring the lifestyle of the subjects of the declaration is determined by the National Agency» (LAW No. 1700-VII, 2014). That is, the legislator used the wording 'determined', which does not require the adoption of the relevant legal act. Instead, in the case of the use of the wording 'approved' - this is mandatory, e.g., as stated in Part 4 of Art. 14 or Part 2 of Art. 37 of the Law of Ukraine «On the Prevention of Corruption» (LAW No. 1700-VII, 2014). Evidently, this argument does not mean that the existence of a normative procedure for monitoring the lifestyle of the declarants will not promote the principles of the rule of law and good governance in the practice of preventing corruption, but allows to carry out these activities without regulatory detail.

As a result, since 2020 Ukraine has been monitoring the lifestyle of declaring entities, but with some caveats. It is a question of limited application of this anti-corruption tool to judges of general courts and Justices of the Constitutional Court of Ukraine. The groundbreaking decision of the Constitutional Court of Ukraine on the inconsistency of certain provisions of the Law of Ukraine "On the Prevention of Corruption" (Decision No. 13-r / 2020, 2020) with the Constitution did not allow for the application of lifestyle monitoring to the subjects of the declaration among the judiciary, including of the Constitutional Court of Ukraine.

An attempt to rectify the situation was embodied in a draft decision of the National Agency for the Prevention of Corruption, which approved the procedure for monitoring the lifestyle of a judge (Decision No. 281/o/15-21, 2021). However, the High Council of Justice commented on the proposed draft on the grounds of the absence of such a model of relations that would exclude undue pressure, influence or control by the executive or legislature on the judiciary and prevent the emergence of regulations that will allow to control the judiciary at the legislative level. Among the main shortcomings of the procedure are: lack of definition of a clear procedure for monitoring the lifestyle of judges, lack of indication of deadlines and requirements for verification of information on the basis of which monitoring of judges' lifestyle begins (Decision No. 281/0/15-21, 2021).

It is obvious that the substantive characteristics of monitoring the lifestyle of the subject of the declaration as a tool to prevent corruption, etymologically makes it impossible to resolve these aspects. Therefore, the tactics of positioning civil servants - representatives of the judiciary as a group of entities to which anti-corruption measures should be applied in a special and radically contradictory manner in the long run will be insignificant from the point of view of its perception by the international community. A similar situation concerns the removal of an assistant judge 
from the list of subjects of declaration in general in accordance with the Law of Ukraine 'On Intelligence Service' (LAW No. 912-IX, 2020.).

\section{Conclusions}

The article investigates the anti-corruption mechanism in terms of a combination of institutional and instrumental systems aimed at preventing corruption in the public and partly private sector. It has been established that the priority directions of transformation of the mechanism for prevention of corruption are: a) enhancement of responsibility for commission of corruption offenses; b) implementation and proper application of tools aimed at detecting corruption.

The reductive tendencies of positive practice of application of preventive tools for corruption prevention in Ukraine have been revealed. Vector changes in the anti-corruption mechanism that create a temporal possibility of continuing the latency of corruption offenses are identified. It is noted that the positive effect of the introduction of monitoring the lifestyle of the subjects of the declaration has not been corroborated in practice due to the following factors: 1) from the moment of introduction of this measure of anti-corruption financial control until now, the order of carrying out monitoring of lifestyle has not been adopted; 2) the lack of differentiation of certain aspects of the application of life monitoring to specific subjects of declaration, which is associated with the specifics of their functions; 3) accompanying phenomena that indirectly affected the lack of priority in resolving problematic issues in the application of lifestyle monitoring.

\section{Bibliographic References}

BILA-TIUNOVA, Liubov; BILOUS-OSIN, Tetiana; KOZACHUK, Diana, \& VASYLKIVSKA, Victoriia. 2019. "Participation of civil society in public administration: prospects for international experience implementation in Ukraine" In: Humanities \& Social Sciences Reviews. Vol. 7, No. 5, pp. 757-764. URL: Available online. In: https://doi.org/10.18510/ hssr.2019.7594. Date of consultation: 14/04/2021.

DECISION No. 13-r /. 2020. On the constitutional petition of 47 people's deputies of Ukraine on compliance with the Constitution of Ukraine (constitutionality) of certain provisions of the Law of Ukraine "On Prevention of Corruption", Criminal Code of Ukraine. Constitutional Court of Ukraine, Kyiv. Ukraine, 2020. Available online. In: https:// zakon.rada.gov.ua/laws/show/v013p710-20\#Text. Date of consultation: 14/04/2021. 
DECISION No. 2017. 2017. Report on the activities of the National Agency for the Prevention of Corruption. National Agency for the Prevention of Corruption, Kyiv. Ukraine, 2017. Available online. In: https://nazk.gov. ua/wp-content/uploads/2019/o7/dodatok_2_zvit_pro_diyalnist.pdf. Date of consultation: 14/04/2021.

DECISION No. 2018. 2018. Report on the activities of the National Agency for the Prevention of Corruption. National Agency for the Prevention of Corruption, Kyiv. Ukraine, 2018. Available online. In: https://nazk. gov.ua/wp-content/uploads/2020/04/Zvit2018-1-1.pdf. Date of consultation: 14/04/2021.

DECISION No. 2019. 2019. Report on the activities of the National Agency for the Prevention of Corruption in 2019. National Agency for the Prevention of Corruption, Kyiv. Ukraine, 2019. Available online. In: https://nazk.gov. ua/wp-content/uploads/2020/o4/Zvit-NAZK-za-2019-rik-15.04.2020. pdf. Date of consultation: 14/04/2021.

DECISION No. 2020. 2020. Report on the activities of the National Agency for the Prevention of Corruption in 2020. National Agency for the Prevention of Corruption, Kyiv. Ukraine, 2020. Available online. In: https://nazk.gov.ua/wp-content/uploads/2021/o4/NAZK-Zvit-za2020-rik-15.04.2021-1-1.pdf. Date of consultation: 14/04/2021.

DECISION No. 281/o/15-21. 2021. On providing comments and suggestions to the raft Procedure for monitoring the lifestyle of a judge. High Council of Justice, Kyiv. Ukraine, 2021. Available online. In: https://hcj.gov.ua/ $\mathrm{doc} / \mathrm{doc} / 6010$. Date of consultation: 14/04/2021.

DECISION No. 32. 2017. Report on the activities of the National Agency for the Prevention of Corruption for 2016. National Agency for the Prevention of Corruption, Kyiv. Ukraine. Available online. In: https://nazk.gov.ua/ wp-content/uploads/2021/02/NAPK_annual-report_2016.pdf. Date of consultation: 14/04/2021.

DRAFTDECISION No.13.2017. On the approval of the procedure for monitoring the lifestyle of declaring subjects. National Agency for the Prevention of Corruption, Kyiv. Ukraine, 2017. Available online. In: https://nazk.gov. ua/wp-content/uploads/2020/11/Do-p.-13-1.pdf. Date of consultation: 14/06/2021.

DRAFT LAW No. 2017. 2017. On the Anti-Corruption Strategy for 2018-2020. Bulletin of the Verkhovna Rada of Ukraine, Kyiv. Ukraine. Available online. In: https://nazk.gov.ua/uk/discussion/proekt-zakonu-ukrayinypro-zasady-derzhavnoyi-antykoruptsijnoyi-polityky-v-ukrayiniantykoruptsijna-strategiya-na-2018-2020-roky/. Date of consultation: 14/06/2021. 
DRAFT LAW No. 2020. 2020. On the Principles of State Anti-Corruption Policy for 2020-2024. Bulletin of the Verkhovna Rada of Ukraine, Kyiv. Ukraine. Available online. In: https://nazk.gov.ua/uk/antykoruptsijnastrategiya/. Date of consultation: 14/06/2021.

GENERAL ASSEMBLY. 1996. International Code of Conduct for Public Officials. Available online. In: https://zakon.rada.gov.ua/laws/ show/995_788\#Text. Date of consultation: 14/06/2021.

HNATOVSKA, Aliona; MANZHOSOVA, Olena; MARUSHCHAK, Anna; OLEKSIY, Uliana. 2019. "The Place of Cryptocurrency in the System of Financial Instruments" In: Amazonia Investiga. Vol. 8, No. 24, pp. 260266.

HUDKOV, Denys. 2018. Administrative and legal means of preventing and combating corruption: dissertation of Candidate of Law. Sumy. Zaporizhzhia National University.

KHABAROVA, Tetiana 2017. Administrative and procedural principles of corruption prevention in Ukraine. Doctoral thesis. Kharkiv. National Legal Yaroslav the Wise University.

KHAMKHODERA, Oleh. 2020a. Insignificance of administrative misconduct regarding the conflict of interest: acceptability and criteria. Izdevniecība "Baltija Publishing". Riga.

KHAMKHODERA,Oleh.2020b.Regardingtheanti-corruption'professionalism' of the presidential poll. Legal aspects of public administration: theory and practice materials of the XII scientific-practical conference (December 17, 2020, Dnipro), pp. 171-174.

KIVALOV, Serhii. 2020. "Ensuring the Human Rights and Freedoms in the Context of the Pandemic Covid-19. Ius Humani” In: Law Journal. Vol. 9, No. 2, pp. 1-23.

KORNUTA, Liudmila; GOLOYADOVA, Tetiana; ZAVHORODNIa, Yuliia; REVA, Yurii. 2020. "Anti-Corruption Declaration as a Measure of Control for the Activities of Subjects of Public Authorities" In: Journal of Environmental Treatment Techniques. Volume 8, No. 4, pp. 1504-1509.

LAW No. 1079-IX. 2020. "On the Amendments to the Law of Ukraine 'On the Prevention of Corruption' Concerning the Restoration of the Institutional Mechanism for the Prevention of Corruption" In: Bulletin of the Verkhovna Rada of Ukraine, Kyiv. Ukraine. Available online. In: https:// zakon.rada.gov.ua/laws/show/1079-20\#Text. Date of consultation: 14/06/2021. 
LAW No. 140-IX. 2019. On Amendments to Certain Legislative Acts of Ukraine Concerning Ensuring the Effectiveness of the Institutional Mechanism for Preventing Corruption. Bulletin of the Verkhovna Rada of Ukraine, Kyiv. Ukraine. Available online. In: https://zakon.rada.gov.ua/laws/ show/140-20\#n184. Date of consultation: 14/06/2021.

LAW No. 1682-VIII. 2014. On the Purification of Power. Bulletin of the Verkhovna Rada of Ukraine, Kyiv. Ukraine. Available online. In: https:// zakon.rada.gov.ua/laws/show/1682-18\#Text. Date of consultation: 14/06/2021.

LAW No. 1698-VII. 2014. On the National Anti-Corruption Bureau of Ukraine. Bulletin of the Verkhovna Rada of Ukraine, Kyiv. Ukraine. Available online. In: https://zakon.rada.gov.ua/laws/show/1698-18\#Text. Date of consultation: 14/06/2021.

LAW No. 1699. 2014. On the Principles of State Anti-Corruption Policy in Ukraine (Anti-Corruption Strategy) for 2014-2017. Bulletin of the Verkhovna Rada of Ukraine, Kyiv. Ukraine. Available online. In: https:// zakon.rada.gov.ua/laws/show/1699-18\#Text. Date of consultation: 14/06/2020.

LAW No. 1700-VII. 2014. On the Prevention of Corruption. Bulletin of the Verkhovna Rada of Ukraine, Kyiv. Ukraine. Available online. In: https:// zakon.rada.gov.ua/laws/show/1700-18\#Text. Date of consultation: 14/06/2020.

LAW No. 2447-VIII. 2018. On the Supreme Anti-Corruption Court. Bulletin of the Verkhovna Rada of Ukraine, Kyiv. Ukraine. Available online. In: https://zakon.rada.gov.ua/laws/show/2447-19\#Text. Date of consultation: 14/06/2020.

LAW No. 912-IX. 2020. On Intelligence Service. Bulletin of the Verkhovna Rada of Ukraine, Kyiv. Ukraine. Available online. In: https://zakon.rada. gov.ua/laws/show/912-20\#Text. Date of consultation: 14/06/2020.

MYKHAILENKO, Dmitrii. 2017. Counteraction to corruption crimes by means of criminal law: conceptual bases: monograph. Helvetica House. Odessa, Ukraine.

OFFICE OF THE PRESIDENT OF UKRAINE. 2021. The Official web-site. Available online. In: https://www.president.gov.ua/news/volodimirzelenskij-ogolosiv-usi-zapitannya-zagalnonacionaln-64629. Date of consultation: 28/06/2021.

ORDER No. 125. 2020. On the Approval of the Regulations on the Specialized Anti-Corruption Prosecutor's Office. Office of the Prosecutor General, 
Kyiv. Ukraine. Available online. In: https://zakon.rada.gov.ua/laws/ show/v0125905-20\#Text. Date of consultation: 28/06/2021.

RESOLUTION No. 118. 2015. On the Establishment of the National Agency for the Prevention of Corruption. Cabinet of Ministers of Ukraine, Kyiv. Ukraine. Available online. In: https://zakon.rada.gov.ua/laws/ show/118-2015-\%Do\%BF\#Text. Date of consultation: 28/06/2021.

RESPONSE No. 2021. 2021. National Agency for the Prevention of Corruption, Kyiv. Ukraine. Available online. In: https://dostup.pravda. com.ua /request/83521/response/235663/attach/1/..pdf?cookie_ passthrough=1. Date of consultation: 28/06/2021.

UNITEDNATIONS. 1997. Lima Convention. Availableonline. In: https://zakon. rada.gov.ua/laws/show/998_090. Date of consultation: 28/06/2021.

UNITED NATIONS. 2003. Convention against Corruption. Available online. In: https://zakon.rada.gov.ua /laws/show/995_c16. Date of consultation: 28/06/2021. 

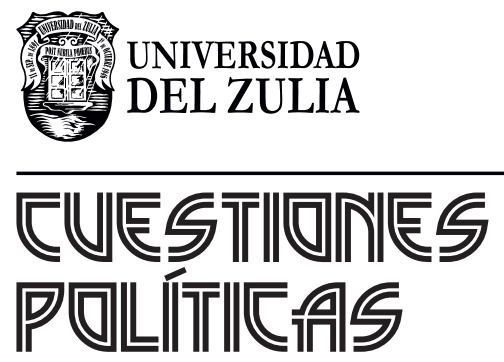

Vol. 39 N $^{\circ} 71$

Esta revista fue editada en formato digital y publicada en diciembre de 2021, por el Fondo Editorial Serbiluz, Universidad del Zulia. Maracaibo-Venezuela 